\title{
ANATRICHOSOMA HAYCOCKI SP. N. (NEMATODA : TRICHURIDAE) FROM THE PARACLOACAL GLANDS OF ANTECHINUS SPP.
}

\author{
With notes on Skrjabinocapillaria Skarbilovitsch
}

\author{
D. M. SPRATT*
}

SUMMARY. Anatrichosoma haycocki sp. n. (Nematoda: Trichuridae) is described from the paracloacal glands of Antechinus swainsonii (Waterhouse, 1840) and A. stuartii Macleay, 1841 (Marsupialia: Dasyuridae) from Nadgee State Forest, New South Wales, Australia. Immature male and female worms occur free in the intestine. A. haycocki is distinguished from other species of Anatrichosoma by the following suite of morphological characters: small size, absence of longitudinal cuticular striations in both sexes, subterminal constriction of male tail bearing 14 minute papillae and inflation of posterior portion of mature female giving Trichuris-like appearance. It is also characterised by its occurrence in paracloacal glands in a genus of small carnivorous dasyurid marsupial restricted to Australia and New Guinea.

Skrjabinocapillaria rodentium Wertheim and Chabaud, 1979 is recognised as a synonym of Anatrichosoma gerbillis (Bernard, 1964). The genus Skrjabinocapillaria Skarbilovitsch, 1946 is placed as a synonym of Capillaria Zeder, 1800, resulting in the new combination for the type species : C. eubursata (Skarbilovitsch, 1946) comb. nov.

It is suggested that deep penetration of the female uterus by the male at insemination is a behavioural feature common to members of the Trichinelloidea and that the morphology of the male reproductive tract reflects the mechanisms of penetration employed by members of each genus.

\section{Anatrichosoma haycocki sp. n. (Nematoda : Trichuridae) des glandes paracloacales d'Antechinus spp., et remarques sur Skrjabinocapillaria Skarbilovitsch.}

RÉSUMÉ. Anatrichosoma haycocki sp. n. (Nematoda: Trichuridae) est décrit des glandes paracloacales d'Antechinus swainsonii (Waterhouse, 1840) et d'A. stuartii Macleay, 1841 (Marsupialia: Dasyuridae) de Nadgee State Forest, New South Wales, Australie. Les mâles et les femelles immatures sont libres dans l'intestin grêle. A. haycocki est distinct des autres espèces d'Anatrichosoma par l'ensemble des caractères suivants : petite taille, absence de stries cuticulaires longitudinales dans les deux sexes, présence chez le mâle d'une petite constriction sub-

* Division of Wildlife Research, CSIRO, P.O. Box 84, Lyneham, A.C.T. 2602, Australia. Accepté le 6 octobre I981. 
terminale et de 14 petites papilles caudales, région postérieure des femelles mûres gonflée comme chez Trichuris; en outre, la localisation (glandes paracloacales) et l'hôte (petit marsupial dasyuride d'Australie et de Nouvelle-Guinée) sont particuliers.

Skrjabinocapillaria rodentium Wertheim et Chabaud, 1979 est mis en synonymie avec Anatrichosoma gerbillis (Bernard, 1964). L'espèce type de Skrjabinocapillaria, S. eubursata Skarbilovitsch, 1946, est un Capillaria, (C. eubursata n. comb.) et le genre Skrjabinocapillaria tombe en synonymie avec Capillaria Zeder, 1800.

La pénétration profonde du mâle dans l'utérus au moment de l'accouplement paraît être un comportement commun aux membres des Trichinelloidea; la morphologie de l'appareil génital mâle paraît traduire les diverses modalités de pénétration existant chez les différents genres.

\section{Introduction}

Beveridge and Barker (1976) reported an undescribed nematode in histological sections of the paracloacal glands of Antechinus stuartii Macleay, 1841, in Victoria. Since 1978 trichinelloid nematodes have been known encapsulated in the cloacal lumen and free in the paracloacal glands of $A$. swainsonii (Waterhouse, 1840) and A. stuartii in southeastern New South Wales. These represent a new species of Anatrichosoma Smith and Chitwood, 1954, (Trichuridae), the first known from Australia and named in honour of Mr Peter Haycock, who collected most of the material.

\section{Materials and Methods}

Specimens were fixed in hot $10 \%$ neutral buffered formalin and stored in $70 \%$ ethanol. They were studied after clearing in lactophenol or pure glycerin. All measurements are in microns unless otherwise indicated, the range followed by the mean in parentheses. Illustrations were made with the aid of a Leitz drawing tube.

\section{Anatrichosoma haycocki sp. n.}

$$
\text { (pl. } 1 \text { fig. 1-12) }
$$

\section{TYPE SPECIMENS}

Holotype: Male, South Australian Museum, (Adelaide) No. V2859.

Allotype: Female, South Australian Museum, (Adelaide) No. V2860.

Paratypes: South Australian Museum (Adelaide) Nos. V2861 - V2864, 4 males; Nos. V2865-V2869, 5 females (A. swainsonii). United States National Museum of Natural History (USNM) Helm. Coll. No. 76547, 2 males, 7 females (A. swainsonii). 

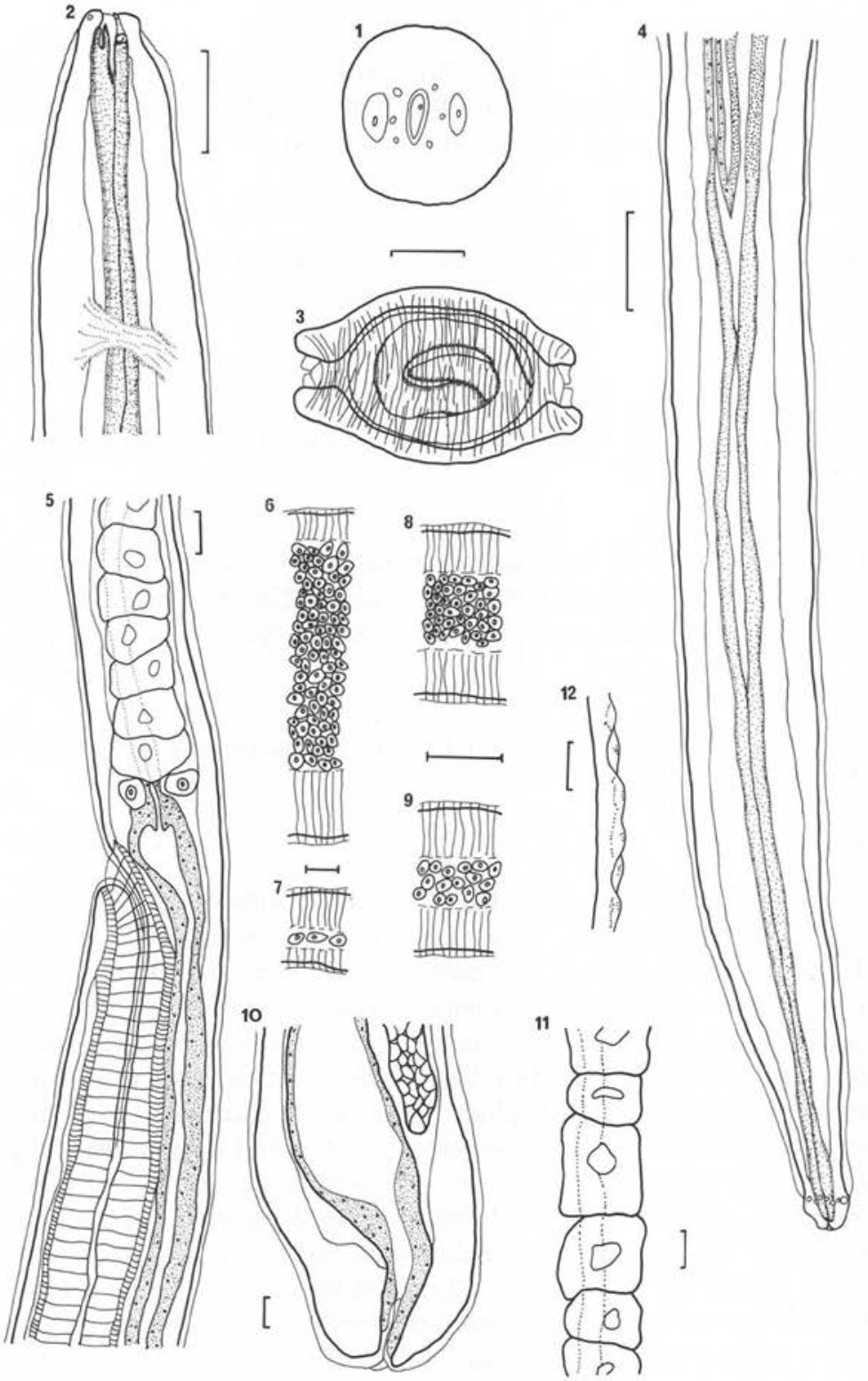

Plate I. - Anatrichosoma haycocki sp. n. from Antechinus spp.

Fig. I. Diagrammatic representation cephalic end, in face view, female. - Fig. 2. Cephalic end male, lateral view. - Fig. 3. Egg. - Fig. 4. Posterior end male, ventral view. - Fig. 5. Vulval region, female, lateral view. - Fig. 6. Bacillary band, female, posterior to vulva. Fig. 7. Bacillary band male, near tail tip. - Fig. 8. Bacillary band, female, near commencement of stichosome. - Fig. 9. Bacillary band, male, near commencement of stichosome. Fig. Io. Posterior end female, latero-ventral view. - Fig. II. Stichocytes, mid-stichosome, male. - Fig. I2. Bacillary band, female, latero-ventral view.

Scale $0.02 \mathrm{~mm}$. 


\section{Additional specimens}

British Museum Coll. No. 1981. 3360-3373, 10 males, 4 females (A. stuartii). Muséum national d'Histoire naturelle (Paris) No. 106 MC. bocal N438, 3 males and posterior end, 3 females and anterior end (A. stuartii).

Hosts

Antechinus swainsonii (Waterhouse, 1840) and Antechinus stuartii Macleay, 1841 (Marsupialia: Dasyuridae); Swainson's marsupial mouse and Brown marsupial mouse.

\section{Locality}

Australia: New South Wales: Nadgee State Forest, south of Eden.

\section{Site of infection}

Mature males in epithelial lining of paracloacal glands or in connective tissue around glands, mature females free in paracloacal glands or encapsulated in lumen of cloaca. Immature males and females free in intestine.

\section{Prevalence of infection}

Found in 5 of 22 female and 3 of 17 male A. swainsonii and in 2 of 17 female and 0 of 4 male $A$. stuartii.

\section{Description}

Trichinelloidea (Ward, 1907), Hall, 1916, Trichuridae (Ransom, 1911), Railliet, 1915, Trichosomoidinae Hall, 1916, Anatrichosoma Smith and Chitwood, 1954. Small slender nematodes; males attenuated posteriorly, shorter and approximately one-quarter maximum diameter of female; mature female with Trichuris-like shape, narrow anterior to vulva, markedly inflated posterior to vulva; unfertilised females more uniform in width and narrow like males. Cuticle relatively thin, with fine transverse striations, without cephalic cuticular expansion, cuticular bullae or preintestinal bulge or constriction; female without dorsal hypodermal ridges. Lateral bacillary bands present in both sexes, commencing near cephalic region as narrow bands one gland cell wide, quickly broadening to 2-4 gland cells wide in male and 12-13 gland cells wide in female, terminating in tail region as narrow band of single cells in male and as broad band of 10-12 cells in female; gland cells frequently raised and noticeably dome-shaped in appearance, particularly in females; apex of dome bearing pore of gland cell. Lateral alae not observed. Cephalic extremity minute, oral opening dorso-ventrally elongated; six minute cephalic papillae around mouth, two large amphids located posterior to circle of papillae; buccal capsule small, containing large blunt dorsal stylet. Oesophagus muscular, narrow anteriorly, broadening posteriorly then narrowing again as it enters stichosome, passing through stichocytes laterally. Stichosome composed of 71-91 stichocytes, longer than wide 
and regularly aligned anteriorly, wider than long and irregularly disposed posteriorly, each with large nucleus. Oesophagus approximately one-third body length in males, approximately one-seventh body length in females. Oesophago-intestinal junction with conspicuous sphincter and two conspicuous mesenchymal cells with prominent nuclei. Rectum and cloaca with modest muscular walls and thin cuticular lining; anus terminal or marginally subterminal.

Male (8 mature, in epithelial lining of paracloacal glands or in connective tissue around glands): Body 8.6-10.5 (9.6) mm long; maximum diameter 50-70 (58), diameter at nerve ring 30-40 (35), diameter at oesophago-intestinal junction 40-60 (50). Nerve ring 81-111 (98) from cephalic end. Oesophagus 3.33-3.53 (3.43) $\mathrm{mm}$ long, muscular portion 242-330 (272) long. Stichosome 3.06-3.26 (3.16) mm long, of 83-91 stichocytes. Cloaca 193-212 (200) long, ejaculatory duct and spicule absent. Tail with subterminal constriction surrounded by circlet of 14 small papillae.

(4 immature, free in small intestine): Body 7.9-9.7 (8.6) mm long; maximum diameter 45-50 (48), diameter at nerve ring 30, diameter at oesophago-intestinal junction 40-50 (42). Nerve ring 56-82 (68) from cephalic end. Oesophagus 1.003.35 (3.20) mm long, muscular portion 130-235 (178) long. Stichosome 0.83-3.17 (2.01) mm long, of 89-92 stichocytes, cells frequently longer than wide. Cloaca 125-235 (175) long, ejaculatory duct and spicule absent. Tail with inconspicuous subterminal constriction surrounded by circlet of 14 small inconspicuous papillae. Sperm present in genital tract.

Female (8 mature, encapsulated in cloaca): Body 6.4-19.9 (11.7) mm long; maximum diameter $162-310$ (252), diameter at nerve ring 30-41 (36), diameter at vulva 63-100 (82). Nerve ring 51-102 (83) from cephalic end. Oesophagus 1.381.98 (1.70) mm long, muscular portion 200-243 (222) long. Stichosome 1.17-1.78 (1.48) $\mathrm{mm}$ long, of 71-85 stichocytes. Vulva 1.40-2.00 (1.72) $\mathrm{mm}$ from cephalic end; muscular ovejector 130-220 (172) long. Rectum 102-119 (110) long. Tail blunt, without constriction or spines.

(4 immature, free in small intestine): Body 6.7-8.9 (7.6) mm long; maximum diameter 55-70 (65), diameter at nerve ring 20-42 (32), diameter at vulva 50-59 (53). Nerve ring 24-78 (51) from cephalic end. Oesophagus 1.52-2.75 (1.87) mm long, muscular portion 80-240 (187) long. Stichosome 1.31-2.67 (1.68) mm long, of more than 72 stichocytes, cells frequently longer than wide. Vulva 1.52-1.65 (1.57) $\mathrm{mm}$ from cephalic end; muscular ovejector 91-246 (164) long. Rectum 36-66 (45) long. Tail blunt, without constriction or spines. Some ova present in genital tract but no sperm observed.

Egg: Bipolar, $69-79$ (75) long; 44-46 (45) maximum width, 33-41 (37) minimum width, flattened in one profile, rounded in opposite giving markedly different widths depending upon orientation of egg when measuring. Egg without protruding plugs, very thick-shelled, with almost squared distal extremities. Shell with fine irregular slightly wavy transverse striations; darkly tanned. Eggs in distal uterus embryonated and containing larvae. 


\section{Discussion}

Species of Anatrichomosa typically are found in tunnels or burrows in epithelial tissue, female worms usually in superficial layers and males frequently in the deeper tissues (Swift et al. 1922; Smith and Chitwood 1954; Chitwood and Smith 1958; Bernard 1964; Pence and Little 1972; Conrad and Wong 1973; File 1974; Long et al. 1976). They are known from mucosal epithelium of the nasal passages of Asian and African monkeys (A. cynamolgi Smith and Chitwood, 1954 (synonyms A. rhina Conrad and Wong, 1973 and A. nacepobi Conrad and Wong, 1973)), the stomach mucosa of Gerbillus pyramidum Geoffroy (A. gerbillis (Bernard, 1964)), the buccal mucosa of Didelphis virginiana Kerr (misidentified as D. marsupialis Linnè) (A. buccalis Pence and Little, 1972) and from the squamous epithelium of sclera, cornea and palpebral conjunctivae of Tupaia glis (Diard) (A. ocularis File, 1974).

A. haycocki is readily distinguished from other members of the genus by the following suite of characters: small size, presence of fine transverse cuticular striations in both sexes, subterminal constriction of the male tail bearing circlet of 14 small papillae and inflation of posterior portion of mature female giving a Trichurislike appearance. These morphological characters and the occurrence of $A$. haycocki in paracloacal glands of a genus of small carnivorous dasyurid marsupial found only in Australia and New Guinea warrant erection of the new species.

In both measurements and morphological characters $A$. haycocki most closely resembles $A$. ocularis. It may be distinguished from $A$. ocularis by its greater length, longer oesophagus and stichosome $(2 \mathrm{x}$ in males), difference in the ratio of oesophageal length: total body length (smaller in males, larger in females), greater number of stichocytes and more posterior position of vulva.

Chitwood and Smith (1958) recorded longitudinal cuticular striae in their detailed redescription of $A$. cynamolgi although Long et al. (1976) referred to transverse striae in the same species. All other species of Anatrichosoma except A. haycocki possess longitudinal cuticular striae. Cephalic cuticular inflations have been described in females of all species except $A$. ocularis and $A$. haycocki, and an inflated posterior portion of the female body occurs in A. gerbillis and A. haycocki. None or as many as 4 pairs of small caudal papillae have been described on the male tail of all species but no species have been reported with a caudal constriction bearing a circlet of 14 small papillae.

The cephalic structures of only A. cynamolgi have been studied in detail. $A$. haycocki resembles this species in the dorso-ventral elongation of the oral opening and the stylet, present in both sexes. The cephalic end differs from that of A. cynamolgi in having a circle of six rather than ten papillae (one cephalic papilla apparently having been lost in each quadrant), and in the exceptionally large size of the amphids.

The lateral bacillary bands in $A$. haycocki are characteristic. In the female partulicarly, bands are wide and gland cells and their pores are frequently raised and dome shaped. In this respect they resemble the structures described as 'dorsal 
hypodermal ridges' posterior to the vulva in female $A$. ocularis (File, 1974) and described as 'papillae' in female A. gerbillis (Bernard, 1964; Pence and Little, 1972), Trichosomoides crassicauda (Bellingham, 1840) Railliet, 1895 and $T$. nasalis (Biocca and Aurizi, 1961). The author has studied types of $T$. nasalis and specimens from Australian rodents. The hypodermal gland cells of the lateral bacillary bands are raised and papilliform in shape and have at their apex the pore opening of the gland cell. The hypodermal ridges described and illustrated by File (1974) in A. ocularis probably represent a dorsal bacillary band.

Gravid females of $A$. haycocki were found free in paracloacal glands and in fibrous capsules of host origin in the lumen of the cloaca, a habitat which is not typical of congeners in which females occur in tunnels in epithelial tissue. Males recovered from the small intestine were smaller than those from paracloacal glands or subcutaneous tissue but contained sperm; however, females from the intestine were unfertilised. Presumably adult worms migrate from the intestine to their final sites and fertilisation occurs in paracloacal glands. Numerous larvated eggs were found in the waxy secretions of the glands.

Bernard (1964) described Trichosomoides gerbillis from the stomach of Gerbillus pyramidum Geoffroy in Tunisia; the species was later transferred to Anatrichosoma (Pence and Little, 1972).

Wertheim and Chabaud (1979) described Skrjabinocapillaria rodentium from the stomachs of Meriones crassus Sundevall, Acomys cahirinus (Desmarest), Gerbillus dasyurus (Wagner), G. gerbillus Olivier and G. pyramidum Geoffroy in Israel. From the description and illustrations it is apparent that theirs is a species of Anatrichosoma, and this was confirmed by examination of one male and two females from the type series. In addition, the following morphological features were observed: two small mesenchymal cells with conspicuous nuclei at the oesophago-intestinal junction, vas deferens not modified distally into a muscular ejaculatory duct, vas deferens and intestine unite and enter cloaca at same level, stichosome in females arranged irregularly in 1, 2 or 3 columns of cells, that in male arranged regularly in a single column of cells.

The specimens of Wertheim and Chabaud correspond closely in both measurements and morphology to the species described by Bernard (1964), except that the lengths of males and females from Israel are greater than those from Tunisia. Consequently, Skrjabinocapillaria rodentium Wertheim and Chabaud, 1979 is placed as a synonym of Anatrichosoma gerbillis (Bernard, 1964).

The genus Skrjabinocapillaria Skarbilovitsch, 1946 is characterized by the absence of a spicule and the presence of an aspinose spicular sheath or cirrus (sensu Rauther, 1909 as quoted in Chitwood and Chitwood, 1950). The type species of this genus, S. eubursata Skarbilovitsch, 1946 was originally described from unidentified bats in USSR. More recently, it has been identified in a spectrum of bat species in Poland (Zdzitowiecki, 1970), USSR (Skvortzov, 1973), Canada (Webster and Casey, 1973) and Cuba (Rutkowska, 1980).

Although unable to examine the types of $S$. eubursata the author has studied the material identified by Zdzitowiecki (1980), Webster and Casey (1973) and by 
Rutkowska (1980). In addition I have seen undetermined specimens from bats in Ontario, Canada. Although difficult to observe in mature male worms because of the deeply plicated cuticular cirrus, a fine, long, non-sclerotised spicule is present in this material. The cirrus in Capillaria may be either spinose or aspinose. The morphological characters of S. eubursata are those of a Capillaria and I propose the new combination C. eubursata (Skarbilovitsch, 1946) comb. nov. Consequently the genus Skrjabinocapillaria falls as a synonym of Capillaria Zeder, 1800.

Little and Orihel (1972) described the unusual mating behaviour of Anatrichosoma buccalis, in which males enter the uterus of the female for up to one-half their length. In the genus Trichosomoides Railliet, 1895 males are permanent inhabitants of the uteri of females, and like males in the genus Anatrichosoma lack both spicules and a muscular ejaculatory duct. In contrast, males of the genus Capillaria Zeder, 1800 probably all possess a spicule and a muscular ejaculatory duct, although the spicule may be extremely difficult to observe in some species because it is weakly or non-sclerotised. In addition, the cuticle of the cloaca in all members of the genus can be everted and this structure serves as a true cirrus, functioning as a conduit for sperm. In some species of Capillaria e.g. C. annulosa (Dujardin, 1845), C. plica (Rudolphi, 1819) the cloaca is exceptionally long and deeply plicated in the body of the male. When fully everted a cirrus several millimeters long is formed, permitting entry deep into the uterus of the female. In the same manner, males of the genera Trichuris Roederer, 1761 and Cystoopsis Wagener, 1867 possess both a spicule and an eversible lining of the cloaca which functions as a cirrus. Male Trichinella Railliet, 1895 possess a vestigial spicule and a cirrus in the form of an eversible lining of the cloaca (Wu, 1955). Consequently, deep penetration of the female uterus at the time of insemination appears to be a behavioural feature common to members of the Trichinelloidea. The mechanisms of penetration employed by males are reflected in the morphology of the distal portion of the reproductive tract in each genus.

AcKNowledgMents - It is a pleasure to acknowledge the advice and comments generously offered by Professor A. G. Chabaud and Dr Odile Bain, Muséum national d'Histoire naturelle, Paris, Dr E. Butterworth, Department of Zoology, University of Alberta, Dr I. Beveridge, Institute of Medical and Veterinary Science, Adelaide, and Dr J. H. Calaby of this Division. Particular thanks are extended to the following individuals for loan of type or other material in their care: Professor A. G. Chabaud; Mrs E. Harris, British Museum (Natural History); Dr J. R. Lichtenfels, United States National Museum; Dr M. A. Rutkowska, Polish Academy of Sciences, and Dr W. A. Webster, National Museums of Canada. The efforts of Mr P. Haycock and Mrs E. Walter in the collection of specimens, Mrs Walter in preparation of illustrations, and Mrs W. Guy in typing the manuscript are gratefully acknowledged. 


\section{BIBLIOGRAPHY}

BERnARD J. : Trichosomoides gerbillis n. sp. parasite stomacal d'un gerbille d'Afrique du nord. Arch. Inst. Past. Tunis., I964, 4I, 33-38.

BEVERIDGe I., BARKer I. K. : The parasites of Antechinus stuartii Macleay from Powelltown, Victoria, with observations on seasonal and sex-related variations in numbers of helminths. Aust. J. Zool., 1976, 24, 265-272.

Brocca E., AURIZI A. : On a new parasitic nematode Trichosomoides nasalis $\mathrm{n}$. $\mathrm{sp}$. from the nasal cavities of Epimys norvegicus : and considerations on the Family Trichosomoididae Yorke and Maplestone, 1926. J. Helminth. R. T. Leiper Supplement, 196I, 5-8.

Conrad H. D., Wong M. M. : Studies of Anatrichosoma (Nematoda: Trichinellida) with descriptions of Anatrichosoma rhina sp. n. and Anatrichosoma nacepobi sp. n. from the nasal mucosa of Macaca mulatta. J. Helminth., 1973, 47, 289-302.

Chrтwood M., Smrth W. N. : A redescription of Anatrichosoma cynamolgi Smith and Chitwood, 1954. Proc. Helm. Soc. Wash., I958, 25, I12-117.

FILE S. K. : Anatrichosoma ocularis sp. n. (Nematoda : Trichosomoididae) from the eye of the common tree shrew, Tupaia glis. J. Parasitol., I974, 60, 985-988.

LitTle M. D., ORIHEL T. C. : The mating behaviour of Anatrichosoma (Nematoda: Trichuroidea). J. Parasitol. 1972, \&8, roI9-1020.

Long G. G., Lichtenfels J. R., Stookey J. L. : Anatrichosoma cynamolgi (Nematoda : Trichinellida) in Rhesus monkeys, Macaca mulatta. J. Parasitol., 1976, 62, I I I-I I5.

Pence D. B., Little M. D. : Anatrichosoma buccalis sp. n. (Nematoda : Trichosomoididae) from the buccal mucosa of the common opossum, Didelphis marsupialis L. J. Parasitol., 1972, s8, 767-773.

RAilliet A. : Traité de Zoologie médicale et agricole, $2^{\mathrm{e}}$ ed. (Fasc. 2) Paris, I895, 25, 737-1303. (From Yorke and Maplestone I926, p. 5. "The Nematode Parasites of Vertebrates".)

RAUTHer M. : Morphologie und Verwandtschaftsbeziehungen der Nematoden. Ergeb. Forstschr. Zool., r9o9, I, 491-596. (From Chitwood and Chitwood 1950, "Introduction to Nemato $\log y^{\prime \prime}$.)

SkvorTzov B. G. : Ecologo-faunicheski obsov gelmintofauni letuchei mishei moldavi. "Parasitit zivotnichi rasteni”. Izdatelstvo, 'Shtiintza' Kishiniev. A cademia Nauk, Moldavskoi SSR, I973.

Smith W. N., Chiтwood M. : Anatrichosoma cynamolgi, a new trichurid nematode from monkeys. J. Parasitol. I954, 40 (Suppl.), I2.

Swift H. F., Boots R. H., Mrller C. P. : A cutaneous nematode infection in monkeys. J. Exp. Med. 1922, 35, 599-620.

Webster W. A., CASEY G. A. : Studies on the parasites of Chiroptera. III. Helminths from various bat species collected in British Columbia. Can. J. Zool, 1973, $51,633-636$.

Wertheim G., Chabaud A. G. : Helminths of birds and mammals of Israel. VIII. - Skrjabinocapillaria rodentium n. sp. (Nematoda: Capillariidae) from gerbillid and murid rodents. Ann. Parasitol. Hum. Comp., 1979, 54, 65-68.

Wu L. Y. : Studies on Trichinella spiralis. I. Male and female reproductive systems. J. Parasitol., I955, 4I, 40-47.

Zdzitowiecki K. : "Helminths of bats in Poland. IV. Nematodes". Acta Parasitol. Pol. ry /o $18,255-265$. 